www.jmscr.igmpublication.org

Index Copernicus Value: 79.54

ISSN (e)-2347-176x ISSN (p) 2455-0450

crossrefDOI: https://dx.doi.org/10.18535/jmscr/v7i2.76

Journal Of Medical Science And Clinical Research

IGM Publication

An Official Publication of IGM Publication

\title{
Hematological Profile in Diagnosing Early Neonatal Sepsis
}

\author{
Authors \\ Mohammad Khushnood ${ }^{1}$, Priya Vijaykumar Gameti ${ }^{2 *}$, Nitin Chaudhary ${ }^{3}$, Mala Jain ${ }^{4}$ \\ ${ }^{1}$ Senior Demonstrator, Government Medical College, Dungarpur, Rajasthan \\ ${ }^{2}$ Assistant Professor, Government Medical College, Dungarpur, Rajasthan \\ ${ }^{3}$ Department of Cytology, AIIMS Jodhpur, Rajasthan \\ ${ }^{4}$ Assistant Professor, Government Medical College, Dungarpur, Rajasthan \\ *Corresponding Author \\ Dr Priya Vijaykumar Gameti \\ Shri Hari Dev Joshi Hospital, Department of Pathology, Government Medical College, Dungarpur
}

\begin{abstract}
Introduction: Systemic infection in first month of life have remained as major cause of mortality and morbidity despite the development of broad spectrum antimicrobial agents. In India incidence of sepsis is 38 per 1000 live births in tertiary care institutes and it contributes to $36 \%$ of deaths in hospitals. To prevent serious morbidity and mortality caused by untreated or late treated neonatal septicemia, it is important that the diagnosis is made early and the treatment is started as early as possible. The present study was aimed to evaluate the neonatal clinical manifestations and their hematological parameters, for rapid identification of early onset neonatal sepsis (EOS).

Material and Methods: This study was conducted at hematology section, Department of pathology, Government Medical College, Dungarpur. Blood samples of the neonates were collected at the time of admission and before initiation of antibiotic therapy. WBC $<5000$ or $>20,000 / \mathrm{mm} 3$ were considered abnormal. Absolute neutrophil count (ANC) was calculated, toxic granules, premature cells also noted.

Observations and Results: A total of 60 neonates were included in which $36 \%$ cases of culture positive and $11 \%$ cases of culture negative presented with low count while $10 \%$ cases of culture positive and $10 \%$ cases of culture negative presented with leucocytosis. Out of 35 proven cases $32 \%$ cases have ANC less than 1800/ $\mathrm{mm}^{3}$ and $26 \%$ cases had $\geq$ to $1800 / \mathrm{mm}^{3}$. (35\%) of proven cases have band cell count more than $20 \% .52 \%$ proven cases showed I/T ratio $\geq 0.2$ while $06 \%$ showed I/T ratio $<0.2 .19$ (31\%) of proven cases showed presence of cytoplasmic vacuoles in neutrophil .41\%) cases showed presence of toxic granules.

Conclusion: It is simple, rapid, cheap and does not need special laboratory facilities which makesit useful in the early detection of neonatal sepsis.
\end{abstract}

Keywords: sepsis, neutrophils, ANC, toxic granules.

\section{Introduction}

Systemic infection in first month of life have remained as major cause of mortality and morbidity despite the development of broad spectrum antimicrobial agents. Overall incidence varies between $1-8$ cases/1000 live births ${ }^{(1)}$. In India incidence of sepsis is 38 per 1000 live births in tertiary care institutes and it contributes to $36 \%$ of deaths in hospitals ${ }^{(2)}$. Although infection can be caused by virus, yeast, and parasite, yet it is 
bacterial infection that play important rolein neonatal sepsis $^{(3)}$. Bacterial infection in the newborn still account for a considerable morbidity and mortality. This is because the newborn especially the premature are prone to serious infections by organisms and partly because the signs of these infections may be absent or minimal and hard to detect ${ }^{(4)}$. To prevent serious morbidity and mortality caused by untreated or late treated neonatal septicemia, it is important that the diagnosis is made early and the treatment is started as early as possible ${ }^{(5)}$. Early onset sepsis (EOS) is defined as sepsis occurring during the first 72 hours oflife as a fetal response to an ascending infection (from the birth canal) or to the hematogenous dissemination of a maternal infection. (MLO). If the exposure occurs in utero or during delivery process, the sepsis is classified as early onset sepsis and if the exposure occurs after birth, it is classified as late onset sepsis ${ }^{(3)}$. "Suspected sepsis" is one of the most frequently encountered diagnosis in neonatology because: a) a large number of newborns are evaluated for early or late sepsis based on risk factors and for fear of missing a correct diagnosis and a prompt treatment; b) in neonates, the clinical signs of infection are not specific, late, and the differential diagnosis with neonatal respiratory distress syndrome, aspiration syndromes, or neonatal maladaptation to extra uterine life is difficult; c) blood culture - the golden standard in neonatal sepsis diagnosis - provides late information, has a poor accuracy, and is not universally available ; and d) we do not have yet an ideal diagnostic tool for neonatal Infection ${ }^{(6)}$. Although blood culture is the "Gold Standard" for the diagnosis of sepsis, reports are available after 48-72 hours and they may be affected by intrapartum antibiotic administration to the mother. Thus, the outcome of a neonate with sepsis largely depends upon its early identification. To meet this end, several rapid diagnostic tests have been described recently. Individual haematological parameters are least affected by antibiotic administration. However, they have low sensitivity and specificity, therefore a combination of these tests was studied by many workers to formulate are liable sepsis screen ${ }^{(7)}$. For the same reason, several rapid haematological tests are done as part of sepsis screen for early diagnosis of neonatal sepsis ${ }^{(2)}$. Sepsis screen $=$ A battery of indirect markers of infection when collectively studied provide an extremely reliable index of neonatal sepsis much earlier and serve as a useful guide for initiating antibiotic therapy ${ }^{(5)}$. The present study was aimed to evaluate the neonatal clinical manifestations and their hematological parameters, for rapid identification of early onset neonatal sepsis $(E O S)^{(2)}$. Peripheral blood smear examination provides information that cannot be obtained from automated cell counting ${ }^{(4)}$. Considering the limited supportive facilities in most area in country; a simple laboratory parameter is necessary which can predict sepsis thus helping the physician in diagnosis and treating neonatal sepsis ${ }^{(3)}$.

\section{Aims and Objective}

Being cheap, simple, rapid and readily available, we aimed at re-evaluating the usefulness of hematological profile as there is still a need for a diagnostic test with high sensitivity, to help improve outcome of septic neonates by alleviating the delay in treatment, and high specificity, to decrease exposure of non-septic neonates to empirical antibiotic therapy.

\section{Materials and Method}

This study was conducted at hematology section, Department of pathology, Government Medical College, Dungarpur.

Neonates in the department of pediatrics were evaluated thoroughly for their clinical course (i.e. gestational age, age of onset, birth weight) were noted. Based on blood culture positivity neonatal sepsis cases were classified as proven and probable sepsis. Blood samples of the neonates were collected at the time of admission and before initiation of antibiotic therapy. Blood sampling was done under all aseptic precautions in the NICU. Soon after admission two ml blood sample was 
taken in EDTA vacutainer and processed for TLC on hematology autoanalyser. TLC $<5000$ or $>20,000 / \mathrm{mm} 3$ were considered abnormal. Blood smear were studied after giemsa stain for morphological features which were looked under 40X and oil immersion using cedar wood oil Neutrophils = hyper segmented, band form, immature to total neutrophil ratio (I/T ratio), Absolute neutrophil count was calculated and toxic granules also noted.

Noted data was entered in excel sheet and analyzed statistically.

Study period: Between August 2018 to January 2019

Sample size: 60 neonates admitted to NICU of pediatric department

Inclusion criteria: Neonates below the age of 28 days with suspected septicemia as per Signs and symptoms mentioned in proforma were included in this study.

Exclusion criteria: Newborn who were diagnosed with highly suspected sepsis and received antibiotic treatment before the samples were collected, had neonatal asphyxia, congenital anomalies, received resuscitation or any invasive procedures before sampling, born from mothers with co-morbid disease other than risk factor for sepsis, received antibiotic treatment for other indication, were not included in the study.

\section{Observations and Results}

Table 1: Gender distribution of cases

\begin{tabular}{|l|c|c|}
\hline \multirow{2}{*}{ Gender } & \multicolumn{2}{|c|}{ Clinical sepsis (Total 60) } \\
\cline { 2 - 3 } & Proven cases & Probable cases \\
\hline Males & $25(41 \%)$ & $17(28 \%)$ \\
\hline Females & $10(17 \%)$ & $08(14 \%)$ \\
\hline Total cases & 35 & 25 \\
\hline
\end{tabular}

A total of 60 neonates were included in this study. Out of which 42 (69\%) were males while 18 (31\%) were females
Table 2: Incidence of Total leucocyte count in cases

\begin{tabular}{|l|c|c|}
\hline \multirow{2}{*}{ Value of total count } & \multicolumn{2}{|c|}{ Clinical sepsis (Total 60) } \\
\cline { 2 - 3 } & Proven cases & Probable cases \\
\hline$<5000 / \mathrm{mm}^{3}$ & $22(36 \%)$ & $07(11 \%)$ \\
\hline$>20000 / \mathrm{mm}^{3}$ & $06(10 \%)$ & $06(10 \%)$ \\
\hline $5000-20000 / \mathrm{mm}^{3}$ & $07(11 \%)$ & $12(21 \%)$ \\
\hline Total cases & 35 & 25 \\
\hline
\end{tabular}

Leucopenia was considered when count was $<5000 / \mathrm{mm}^{3}$ while leucocytosis was considered when count was $>20000 / \mathrm{mm}^{3}$.In our study $22(36 \%)$ cases of culture positive and $07(11 \%)$ cases of culture negative presented with low count. In our study $06(10 \%)$ cases of culture positive and 06 $(10 \%)$ cases of culture negative presented with leucocytosis. 07(11\%) in culture positive and $12(21 \%)$ in culture positive showed WBCs within normal range.

Table 3: Incidence of Absolute Neutrophil Count (ANC) in cases

\begin{tabular}{|l|c|c|}
\hline Value of ANC & \multicolumn{2}{|c|}{ Clinical sepsis (Total 60) } \\
\cline { 2 - 3 } per cubic mm & Proven cases & Probable cases \\
\hline$<1800 / \mathrm{mm}^{3}$ & $16(26 \%)$ & $10(17 \%)$ \\
\hline$\geq 1800 / \mathrm{mm}^{3}$ & $19(32 \%)$ & $15(25 \%)$ \\
\hline Total cases & 35 & 25 \\
\hline
\end{tabular}

Out of 35 proven cases $19(32 \%)$ cases have ANC less than $1800 / \mathrm{mm}^{3}$ and $16(26 \%)$ cases had more than or equal to $1800 / \mathrm{mm}^{3}$ Out of 25 probable cases $10(17 \%)$ cases have ANC less than $1800 / \mathrm{mm}^{3}$ and $15(25 \%)$ cases had more than or equal to $1800 / \mathrm{mm}^{3}$.

Table 4: Incidence of Band Cell count in cases

\begin{tabular}{|l|c|c|}
\hline \multirow{2}{*}{$\begin{array}{l}\text { Value of band } \\
\text { cell count }\end{array}$} & \multicolumn{2}{|c|}{ Clinical sepsis (Total 60) } \\
\cline { 2 - 3 }$\geq 20 \%$ & Proven cases & Probable cases \\
\hline$<20 \%$ & $22(35 \%)$ & $15(26 \%)$ \\
\hline Total cases & $13(22 \%)$ & $10(17 \%)$ \\
\hline
\end{tabular}

Out of 35 proven cases $22(35 \%)$ cases have band cell count more than $20 \%$ and $12(26 \%)$ cases had less than $20 \% 13$ (22\%). Out of 25 probable cases $15(26 \%)$ cases have band cell count more than $20 \%$ and $10(17 \%)$ cases had less than $20 \%$. 
Table 5: Cases showing incidence of positive I/T ratio

\begin{tabular}{|l|c|c|}
\hline \multirow{2}{*}{ I/T ratio } & \multicolumn{2}{|c|}{ Clinical sepsis (Total 60) } \\
\cline { 2 - 3 } & Proven cases & Probable cases \\
\hline$\geq 0.2$ & $31(52 \%)$ & $19(32 \%)$ \\
\hline$<0.2$ & $04(06 \%)$ & $06(10 \%)$ \\
\hline Total cases & 35 & 25 \\
\hline
\end{tabular}

In the present study among the 35 cases of blood culture positive neonates $31(52 \%)$ showed I/T ratio $\geq 0.2$ while $04(06 \%)$ showed $\mathrm{I} / \mathrm{T}$ ratio $<0.2$.Out of 25 probable cases 19 (32\%) showed $\mathrm{I} / \mathrm{T}$ ratio $\geq 0.2$ while $06(10 \%)$ showed $\mathrm{I} / \mathrm{T}$ ratio $<0.2$

Table 6: Cases showing incidence of toxic granulation of neutrophils

\begin{tabular}{|c|c|c|}
\hline \multirow{2}{*}{$\begin{array}{l}\text { Toxic granulations } \\
\text { in neutrophils }\end{array}$} & \multicolumn{2}{|c|}{ Clinical sepsis (Total 60) } \\
\hline & Proven cases & Probable cases \\
\hline Present & $25 \quad(41 \%)$ & $13(21 \%)$ \\
\hline & $10 \quad(17 \%)$ & $12(21 \%)$ \\
\hline Total cases & 35 & 25 \\
\hline
\end{tabular}

Out of 35 proven cases $25(41 \%)$ cases showed presence of toxic granulesand $10(17 \%)$ cases showed absence of toxic granules :Out of 25 probable cases $13(21 \%)$ cases showed presence of toxic granules and $12(21 \%)$ cases showed absence of toxic granules.

Table 7: Cases showing Incidence of positive cytoplasmic vacuoles in neutrophils

\begin{tabular}{|l|c|c|}
\hline $\begin{array}{l}\text { Cytoplasmic } \\
\text { vacuolization } \\
\text { neutrophils }\end{array}$ & \multicolumn{2}{|c|}{ Clinical sepsis (Total 60) } \\
\cline { 2 - 3 } & Proven cases & Probable cases \\
\hline Present & $19(31 \%)$ & $12(20 \%)$ \\
\hline Absent & $16(26 \%)$ & $13(23 \%)$ \\
\hline Total cases & 35 & 25 \\
\hline
\end{tabular}

Out of 35 proven cases 19 (31\%) cases showed presence of cytoplasmic vacuoles in neutrophil and $16(26 \%)$ cases showed absence of cytoplasmic vacuoles in neutrophil. Out of 25 probable cases 12 (20\%) cases showed presence of cytoplasmic vacuoles in neutrophil and $13(23 \%)$ cases showed absence of cytoplasmic vacuoles in neutrophil.

\section{Discussions}

Table 8: Comparison of gender distribution among cases in different studies

\begin{tabular}{|l|c|c|c|c|c|c|c|}
\hline Gender & Kalpana et al & $\begin{array}{c}\text { Dalia et } \\
\text { al }\end{array}$ & Champa et al & $\begin{array}{c}\text { Vandana } \\
\text { et al }\end{array}$ & $\begin{array}{c}\text { Ravindra } \\
\text { et al }\end{array}$ & $\begin{array}{c}\text { Hijrah et } \\
\text { al }\end{array}$ & $\begin{array}{c}\text { Present } \\
\text { study }\end{array}$ \\
\hline Male & $66 \%$ & $57.2 \%$ & $58.9 \%$ & $56.4 \%$ & $58 \%$ & $57.5 \%$ & $69 \%$ \\
\hline Female & $34 \%$ & $42.8 \%$ & $41.1 \%$ & $43.6 \%$ & $42 \%$ & $42.5 \%$ & $31 \%$ \\
\hline
\end{tabular}

In present study neonatal sepsis was more commonly seen in male in comparison to females which consistent with result of other studies.

Table 9: Comparison of total leucocyte count among cases in different studies

\begin{tabular}{|c|c|c|}
\hline \multirow[t]{2}{*}{ Study } & \multicolumn{2}{|c|}{ Clinical sepsis } \\
\hline & Proven cases & Probable cases \\
\hline Champa et al & $\begin{array}{ll}<5000 / \mathrm{mm}^{3} & -15.2 \% \\
5000-20000 / \mathrm{mm}^{3} & -54.3 \% \\
>20000 / \mathrm{mm}^{3} & -30.5 \%\end{array}$ & $\begin{array}{ll}<5000 / \mathrm{mm}^{3} & -8.1 \% \\
5000-20000 / \mathrm{mm}^{3}-71.5 \% \\
>20000 / \mathrm{mm}^{3}-20.4 \%\end{array}$ \\
\hline Ravindra et al & $\begin{array}{ll}<5000 / \mathrm{mm}^{3} \text { or }>20000 / \mathrm{mm}^{3} & -49 \% \\
5000-20000 / \mathrm{mm}^{3} & -51 \%\end{array}$ & $\begin{array}{l}5000 / \mathrm{mm}^{3} \text { or }>20000 / \mathrm{mm}^{3}-35 \% \\
5000-20000 / \mathrm{mm}^{3}\end{array}$ \\
\hline Dalia et al & $\begin{array}{l}<5000 / \mathrm{mm}^{3}-13.7 .2 \% \\
5000-25000 / \mathrm{mm}^{3}-80 \% \\
>25000 / \mathrm{mm}^{3}-06 \%\end{array}$ & \\
\hline Present study & $\begin{array}{ll}<5000 / \mathrm{mm}^{3} & -63 \% \\
5000-20000 / \mathrm{mm}^{3}-17 \% \\
>20000 / \mathrm{mm}^{3}-20 \%\end{array}$ & $\begin{array}{lc}<5000 / \mathrm{mm}^{3} & -28 \% \\
5000-20000 / \mathrm{mm}^{3}-24 \% \\
>20000 / \mathrm{mm}^{3} \quad-48 \%\end{array}$ \\
\hline
\end{tabular}

In present study leukopenia was found to be present in $63 \%$ of proven cases while leucocytosis was found to be in $20 \%$ of proven cases. In other studies maximum cases were found to be within normal range suggesting no diagnostic significance in neonatal sepsis whereas in our study it is found to useful as marker of sepsis. 
Table 10: Comparison of ANC among cases in different studies

\begin{tabular}{|l|c|c|c|c|c|c|}
\hline \multirow{2}{*}{$\begin{array}{l}\text { Value of ANC per } \\
\text { cubic mm }\end{array}$} & \multicolumn{2}{|c|}{ Ravindra et al } & \multicolumn{2}{c|}{ Hijrah et al } & \multicolumn{2}{c|}{ Present study } \\
\cline { 2 - 7 } & $\begin{array}{c}\text { Proven } \\
\text { sepsis }\end{array}$ & $\begin{array}{c}\text { Probable } \\
\text { sepsis }\end{array}$ & $\begin{array}{c}\text { Proven } \\
\text { sepsis }\end{array}$ & $\begin{array}{c}\text { Probable } \\
\text { sepsis }\end{array}$ & $\begin{array}{c}\text { Proven } \\
\text { sepsis }\end{array}$ & $\begin{array}{c}\text { Probable } \\
\text { sepsis }\end{array}$ \\
\hline$<1800$ & $15.3 \%$ & $06 \%$ & $05 \%$ & $45 \%$ & $26 \%$ & $17 \%$ \\
\hline$>1800$ & $54.8 \%$ & $24 \%$ & $23 \%$ & $27 \%$ & $32 \%$ & $25 \%$ \\
\hline
\end{tabular}

The results above show that higher ANC is associated with culture positive cases and also with probable cases except in study by Hijrah et al in which low ANC is associated with more number of probable cases. This result supports previous theories which implied that newborn from mother with infection risk factor and had high ANC are at high risk of neonatal sepsis. In newborn infant, non specific immunity plays crucial role in eliminating pathogens, thus, if the newborn have high ANC it can be inferred that there's some severe infection going on. This prediction is more likely in newborn from mother with infection risk factors $^{(3)}$.

Table 11: Comparison of I/T ratio in neonatal sepsis patients in different studies

\begin{tabular}{|c|c|c|}
\hline \multirow[t]{2}{*}{ Study } & \multicolumn{2}{|c|}{ Clinical sepsis } \\
\hline & Proven cases & Probable cases \\
\hline Champa et al & I/T ratio $>0.2-47.8 \%$ & $\mathrm{I} / \mathrm{T}$ ratio $>0.2-4.08 \%$ \\
\hline Ravindra et al & $\begin{array}{ll}\mathrm{I} / \mathrm{T} \text { ratio } \geq 0.2 & -47 \% \\
\mathrm{I} / \mathrm{T} \text { ratio }<0.2 & -23 \%\end{array}$ & $\begin{array}{ll}\text { I/T ratio } \geq 0.2 & -06 \% \\
\text { I/T ratio }<0.2 & -24 \%\end{array}$ \\
\hline Dalia et al & \multicolumn{2}{|c|}{$\begin{array}{cc}\text { Normal I/T ratio }<0.2 & -34.4 \% \\
\text { Moderate I/T ratio }(0.2-0.29) & -26 \%\end{array}$} \\
\hline Vandana et al & $\begin{array}{ll}\mathrm{I} / \mathrm{T} \text { ratio } \geq 0.2 & -50 \% \\
\mathrm{I} / \mathrm{T} \text { ratio }<0.2 & -50 \%\end{array}$ & $\begin{array}{ll}\mathrm{I} / \mathrm{T} \text { ratio } \geq 0.2 & -23.6 \% \\
\mathrm{I} / \mathrm{T} \text { ratio }<0.2 & -66.4 \%\end{array}$ \\
\hline Present study & $\begin{array}{ll}\mathrm{I} / \mathrm{T} \text { ratio } \geq 0.2 & -52 \% \\
\mathrm{I} / \mathrm{T} \text { ratio }<0.2 & -06 \%\end{array}$ & $\begin{array}{ll}\text { I/T ratio } \geq 0.2 & -32 \% \\
\text { I/T ratio }<0.2 & -10 \%\end{array}$ \\
\hline
\end{tabular}

In the current study it was reported that neutrophil left shift $(\mathrm{I} / \mathrm{T}$ ratio $\geq 0.2)$ was seen in maximum cases of both proven and probable cases which were consistent with most of the studies .During the bacterial infections increased number of neutrophils is released from bone marrow into the blood stream providing neutrophils to migrate at the infected site. This increase in neutrophils appear essential for the host resistant to bacterial infection. As more neutrophils are released, more $\&$ more immature cell reaches the circulation, a process called as "shift to left". This finding have been found valuable in early diagnosis of bacterial infection $^{(5)}$.

Table 12: Comparison of presence of toxic granules in neutrophils in different studies

\begin{tabular}{|c|c|c|}
\hline \multirow[t]{2}{*}{ Study } & \multicolumn{2}{|c|}{ Clinical sepsis } \\
\hline & Proven cases & Probable cases \\
\hline Champa et al & Present $-32.6 \%$ & Present $-00 \%$ \\
\hline Ravindra et al & $\begin{array}{ll}\text { Present } & -41 \% \\
\text { Absent } & -29 \%\end{array}$ & $\begin{array}{ll}\text { Present } & -07 \% \\
\text { Absent } & -23 \%\end{array}$ \\
\hline Kalpana et al & $\begin{array}{ll}\text { Present } & -70.5 \% \\
\text { Absent } & -29.4 \%\end{array}$ & $\begin{array}{cc}\text { Present } & -36.3 \% \\
\text { Absent } & -63.6 \%\end{array}$ \\
\hline Vandana et al & $\begin{array}{cc}\text { Present } & -68.18 \% \\
\text { Absent } & -31.82 \%\end{array}$ & $\begin{array}{cc}\text { Present } & -45.8 \% \\
\text { Absent } & -54.6 \%\end{array}$ \\
\hline Present study & $\begin{array}{ll}\text { Present } & -41 \% \\
\text { Absent } & -17 \%\end{array}$ & $\begin{array}{ll}\text { Present } & -21 \% \\
\text { Absent } & -21 \%\end{array}$ \\
\hline
\end{tabular}

Toxic granules were present in majority of cases in studies while in probable cases toxic granules were proven cases which is in accordance with other absent in most of the cases in present as well as 
other studies. Xanthouin her study of neonatal infection, described toxic granulation as an important feature and that that toxic granulation was invariably present during sepsisa change never seen in healthy new born babies ${ }^{(8)}$.

\section{Conclusions}

Neonatal sepsis is a serious illness associated with high mortality so a high index of suspicion is important in the diagnosis and treatment of neonatal infection because it is hampered by vague and nonspecific clinical manifestations. It is simple, rapid, cheap and does not need special laboratory facilities which makes it useful in the early detection of neonatal sepsis as well as decreasing the exposure of non-septic neonates to antimicrobial therapy.

Future Implications: The accuracy of several biomarkers for diagnosing sepsis, as interleukins (IL6, IL8), CD64, tumour necrosis factor alpha in the early, procalcitoninin the middle and $\mathrm{C}$ reactive protein in the late phases of sepsis, have been studied and seemed promising if collaborated with current diagnostic. hematological parameters like WBC count, I/T ratio, immature PMNs, thrombocytopenia, toxic granules, raised $\mu$-ESR and CRP.

\section{References}

1. IOSR Journal of Dental and Medical Sciences (IOSR-JDMS)e-ISSN: 2279-0853, p-ISSN: 2279-0861. Volume 15, Issue 11 Ver. II (November. 2016), PP 40-43 www.iosrjournals.orgDOI: 10.9790/0853-1511024043

www.iosrjournals.org 40 | Page Clinical Profile, Outcome of Neonatal Sepsis and Statistical Analysis of Sepsis Screening Markers for Early Diagnosis .Dr Kalpana.L

2. Panwar C, Kaushik SL, Kaushik R, Sood A. Correlation of neonatal and maternal clinico-hematological parameters as predictors of early onset neonatal sepsis. Int $\mathbf{J}$ Contemp Pediatr 2017;4:36-42.

3. Hijrah Harmansyah, Ema Alasiry, Dasril Daud. Absolute Neutrophil Count as Predictor of Early Onset Sepsis. Clinical Medicine Research.Vol. 4, No. 3, 2015, pp. 87-91. doi: 10.11648/j.cmr.20150403.15

4. Paramanantham P, Maharaja P. A Study of Peripheral Blood Smear in Neonates. Mod Appl Bioequiv Availab. 2018; 3(4): 555618. DOI: 10.19080/MABB.2018.03.555618 .

5. IOSR Journal of Dental and Medical Sciences (IOSR-JDMS) e-ISSN: 2279-0853, p-ISSN: 2279-0861.Volume 16, Issue 4 Ver. IX (April. 2017), PP 11-17 www.iosrjournals.org DOI: 10.9790/0853-1604091117

www.iosrjournals.org $11 \quad$ Page Haematological Profile in Neonatal Septiceamia Dr.G.Vandana1, Dr.S.Lokesh rao magar2, Dr. Praveen3, Dr.B .Kavita. devi4 Dr. sandhya rani5, Dr.sandhya anil6

6. DOI: $\quad 10.1515 / \mathrm{rrlm}-2016-0042$ Complete blood count and differential indiagnosis of early onset neonatal sepsisMaria Livia Ognean1, Adrian Boicean2, Floredana-Laura Şular3, ${ }^{*}$, Manuela Cucerea3

7. Ravindra Ramteke, Rajendra Madane, Sapna Deshpande. Haematological Profile in Neonatal Sepsis. Med Pulse International Journal of Pathology. May 2018; 6(2): 35-40. https://www.medpulse.in/Pathology/

8. Xanthou M, Leucocyte blood picture in healthy full-term and premature babies during neonatal period. Archives of diseases in childhood1970;45;242-249. 